\title{
DAMPAK TATA KELOLA PERUSAHAAN TERHADAP PROFITABILITAS DAN NILAI PERUSAHAAN: ANALISIS SIMULASI KEBIJAKAN
}

\author{
IMPACT OF CORPORATE GOVERNANCE ON PROFITABILITY AND FIRM VALUE: \\ POLICY SIMULATION ANALYSIS
}

\author{
Assrianti $^{* 1}$, Bonar M. Sinaga*), Bayu Bandono*) \\ *) Sekolah Bisnis, IPB University \\ Jl. Pajajaran Bogor 16151, Indonesia
}

\begin{abstract}
The concept of good corporate governance (GCG) has not been fully implemented by most business actors which is reflected in the assessment results of the ASEAN Corporate Governance Scorecard. The study aims to analyze the impact of external and internal factors including the implementation of GCG on the profitability and firm value in the LQ45 index of the Indonesia Stock Exchange. The econometric model is built as a system of simultaneous equations and estimated by using the Two-Stage Least Squares (2SLS) method and the impact simulation analysis policy. The result shows impact of decrease in gross domestic product is greater than increase in inflation. Furthermore if the decrease in gross domestic product or the increase in inflation that is resolved by company policies by improving corporate governance, making efficiency by reducing operational costs, and increasing total assets, have greater impact than the company resolved by improving corporate governance and making efficiency by reducing the cost of goods sold.
\end{abstract}

Keywords: econometric model, external and internal factors, firm value, good corporate governance, profitability

\begin{abstract}
Abstrak: Konsep tata kelola perusahaan masih belum sepenuhnya diterapkan oleh sebagian besar pelaku usaha yang tercermin dalam hasil penilaian ASEAN Corporate Governance Scorecard. Tujuan penelitian adalah untuk menganalisis dampak faktor eksternal dan internal termasuk penerapan tata kelola perusahaan terhadap profitabilitas dan nilai perusahaan dalam indeks LQ45 Bursa Efek Indonesia. Model ekonometrika dibangun sebagai sistem persamaan simultan dan diestimasi menggunakan metode Two Stage Least Squares (2SLS) dan analisis simulasi dampak kebijakan. Hasil penelitian menunjukkan dampak penurunan produk domestik bruto lebih besar daripada kenaikan tingkat inflasi. Selanjutnya, pada kondisi penurunan produk domestik bruto atau peningkatan tingkat inflasi yang diatasi perusahaan dengan kebijakan meningkatkan tata kelola perusahaan, menurunkan beban operasional, dan meningkatkan total aset memiliki dampak lebih besar dibandingkan dengan yang diatasi perusahaan dengan meningkatkan tata kelola perusahaan dan melakukan efisiensi dengan menurunkan harga pokok penjualan.
\end{abstract}

Kata kunci: faktor eksternal, faktor internal, nilai perusahaan, profitabilitas, tata kelola

\footnotetext{
${ }^{1}$ Alamat Korespondensi:

Email: assrianti20@gmail.com
} 


\section{PENDAHULUAN}

Krisis keuangan yang terjadi di tahun 1997-1998 dan krisis keuangan global pada tahun 2008 yang dipicu oleh skandal suprime mortgage di Amerika Serikat, telah membangkitkan adanya reformasi dan inisiatif baru yang mendorong penguatan perekonomian nasional (OJK, 2014). The Indonesian Institute for Corporate Governance dalam Laporan Corporate Governance Perception Index tahun 2009 menyatakan bahwa, lumpuhnya sektor ekonomi yang memiliki peran signifikan dalam perekonomian Indonesia, membuat International Monetary Fund (IMF) memberikan bantuan dana dengan mensyaratkan adanya peningkatan implementasi tata kelola perusahaan.

The Organization for Economic Co-operation and Development (OECD) (2010) menjelaskan bahwa dalam rangka menjaga stabilisas perekonomian akibat krisis, pasar modal berperan penting sebagai tempat pembiayaan alternatif. Produk Domestik Bruto (PDB) merupakan salah satu indikator makroekonomi utama dalam melihat perekonomian di suatu negara, di mana semakin tinggi nilai PDB mengindikasikan perekonomian pada negara tersebut mengalami pertumbuhan dan menciptakan peningkatan daya beli masyarakat sehingga perusahaan akan berlomba untuk meningkatkan penjualannya. Peningkatan penjualan menandakan kinerja perusahaan yang baik dan hal tersebut akan menaikkan harga saham (Prasetyanto, 2016). Kenaikan harga saham tentunya akan berpengaruh terhadap kapitalisasi pasar modal secara umum.

Gambar 1 menyajikan sejak tahun 2010 - 2018, ratarata kapitalisasi pasar memiliki kontribusi sebanyak $46,88 \%$ terhadap PDB dengan total kapitalisasi pasar sebesar Rp6.667.57 triliun di tahun 2018. Kapitalisasi pasar yang tinggi didukung oleh semakin bertumbuhnya jumlah perusahaan tercatat di Indonesia dari tahun ke tahun. Pada tahun 2018, jumlah perusahaan tercatat meningkat sebesar 3,96\% dari 566 menjadi 619 perusahaan tercatat. Peningkatan jumlah ini turut menjadi suatu indikasi bahwa pasar modal menjadi tempat yang dipercaya oleh entitas sebagai sumber pembiayaan maupun sarana investasi.

Nilai kapitalisasi pasar Indonesia didominasi oleh 45 saham dengan kondisi likuiditas terbaik dan memiliki kinerja yang dapat dipertanggungjawabkan. Di Bursa Efek Indonesia, ke-45 perusahaan tersebut berada dalam sebuah indeks LQ45 yang dapat dijadikan acuan bagi para investor dalam mendukung keputusan investasinya, di mana indeks LQ45 menyumbang sekitar $70 \%$ terhadap kapitalisasi pasar nasional. Fahmi (2014) menyatakan bahwa indeks LQ45 yang sering disebut sebagai saham blue chip, yakni saham perusahaan yang memiliki nilai kondisi yang cenderung stabil dan bersifat mengalami kenaikan yang konstan (constant growth), membuat investor kategori risk adverse (menghindari risiko) cenderung memilih saham di kategori ini. Perkembangan indeks saham pada indeks LQ45 disajikan dalam Gambar 2.

Gambar 2 menyajikan perkembangan indeks LQ45 yang menunjukkan tren peningkatan dan penurunan yang fluktuatif. Pada tahun 2015 telah terjadi penurunan kinerja sebesar $11,86 \%$ dari tahun sebelumnya. Walaupun pada akhirnya di tahun 2016 dan 2017 kinerja saham LQ45 meningkat sebesar 22,02\%, namun di akhir tahun 2018 kinerja kembali menurun sebesar3 $8,96 \%$. Hal ini memberikan indikasi bahwa kondisi saham-saham yang termasuk ke dalam kategori saham dengan kondisi likuiditas baik tidak menjamin adanya kepastian bahwa akan terus terjadi peningkatan kinerja, namun akan dipengaruhi oleh kondisi makroekonomi dan internal masing-masing perusahaan.

Mengacu kepada krisis yang telah terjadi dan penyebabnya, tata kelola merupakan salah satu bentuk upaya mitigasi terhadap risiko sistemik yang seharusnya diimplementasikan dengan baik oleh seluruh perusahaan. Claessens dan Burcin (2012) menjelaskan bahwa krisis keuangan yang terjadi akibat adanya kegagalan tata kelola perusahaan di lembaga keuangan dan perusahaan, berdampak pada timbulnya gugatan hukum yang mengakibatkan kebangkrutan pada perusahaan-perusahaan di dunia dikarenakan banyaknya kasus fraud, skandal akuntansi, dan kegagalan bisnis. Hal tersebut sejalan dengan yang disampaikan Turel et al. (2012) bahwa kegagalan tersebut terjadi akibat lemahnya peran manajemen dalam menjalankan perusahaan.

Committee on The Financial Aspects of Corporate Governance atau yang lebih dikenal dengan Cadbury Committee mendefinisikan tata kelola sebagai prinsip yang mengarahkan dan mengendalikan perusahaan agar mencapai keseimbangan antara kekuatan dan kewenangan perusahaan hal yang terjadi di perusahaan kepada seluruh pemangku kepentingan (stakeholders), khususnya kepada pemegang saham (shareholders) 
(Daniri, 2014). Berdasarkan definisi yang dinyatakan oleh Cadbury Committee, definisi mengenai tata kelola perusahaan kemudian semakin berkembang dari waktu ke waktu. Zarkasyi (2008) mendefinisikan tata kelola merupakan suatu sistem (input, proses, output) dan seperangkat peraturan yang mengatur hubungan antara berbagai pihak yang berkepentingan terutama direksi, dewan komisaris, dan pemegang saham demi tercapainya tujuan perusahaan.

Pemenuhan implementasi tata kelola yang baik merupakan langkah strategik dalam rangka mencapai tujuan didirikannya sebuah perusahaan yang pada umumnya adalah untuk memaksimalisasi kekayaan pemegang saham melalui optimalisasi nilai perusahaan yang diproksikan dengan Tobin's Q serta memperoleh laba, yang dilihat berdasarkan rasio profitabilitasnya, yakni Return on Assets (ROA) dan Return on Equity (ROE). Tjondro dan Wilopo (2011) menyatakan bahwa tata kelola perusahaan yang ditunjukkan melalui variabel pelaksanaan tugas dan tanggung jawab (direksi, dewan komisaris, komite), penanganan benturan kepentingan, pengendalian internal, penyediaan dana pada pihak ketiga, transparansi, dan rencana strategis bank, memiliki pengaruh positif dan signifikan terhadap profitabilitas (ROA dan ROE).

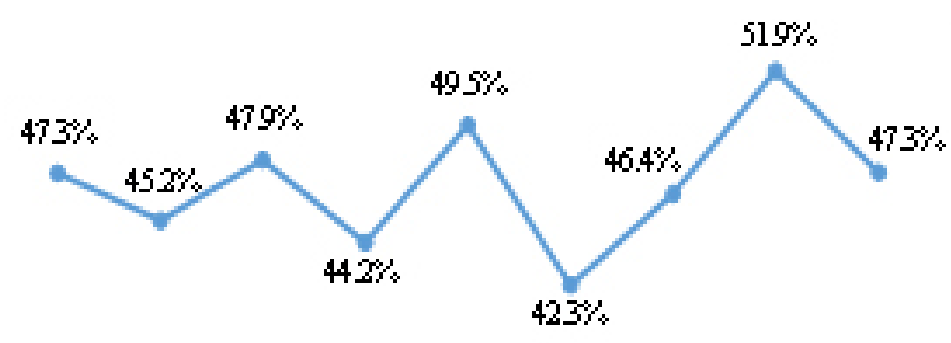

$2010 \quad 2011 \quad 2012 \quad 2013 \quad 2014 \quad 2015 \quad 2016 \quad 2017 \quad 2018$

Gambar 1. Kontribusi kapitalisasi pasar terhadap PDB Indonesia tahun 2010-2018 (CEICData, 2019)

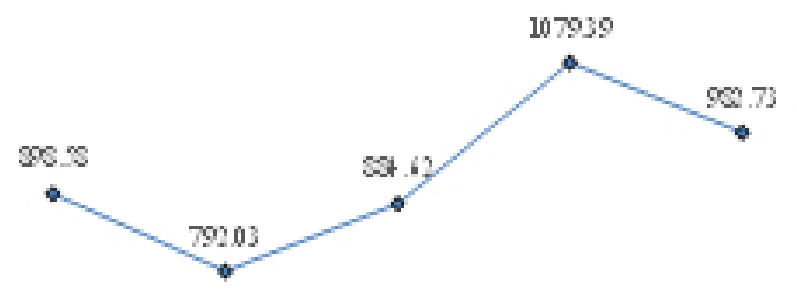

\begin{tabular}{lllll}
\hline 2014 & 2015 & 2016 & 2017 & 2015
\end{tabular}

Gambar 2. Perkembangan Indeks Saham LQ45 (BEI, 2019) 
Penelitian Bhatt dan Bhatt (2017), Attia et al. (2018), Adam et al. (2018), dan Tshipa et al. (2018) juga menyatakan bahwa tata kelola memiliki pengaruh positif dan signifikan terhadap profitabilitas perusahaan. Terkait dengan nilai perusahaan, penelitian Syafitri et al. (2018), Fahdiansyah et al. (2018), menyatakan bahwa tata kelola yang diproksikan melalui variabel komite audit, kepemilikan manajerial, direksi, dan dewan komisaris memiliki pengaruh signifikan terhadap nilai perusahaan. Penelitian tersebut sejalan dengan teori resource dependence yang mengungkapkan bahwa terdapat hubungan yang positif antara ukuran dewan dan kinerja perusahaan (Mardiyati dan Murdayanti, (2016)). Selain itu, agency and stakeholders theories menganggap bahwa kinerja perusahaan berbanding lurus dengan ukuran board. Dalam hal ini, agency theory menyatakan bahwa saat mengontrol, memantau, dan mengevaluasi bisnis perusahaan, member of the board melakukannya dalam rangka memenuhi kepentingan pemegang saham. Stakeholders theory menyatakan bahwa manajemen mewakili seluruh pemangku kepentingan, sehingga ketika seluruh manajemen menggunakan keahlian, kemampuan, pengetahuan, dan pengalamannya dengan optimal, kinerja perusahaan meningkat (Alqatan, 2019). Manajemen sebagai bagian dari organisasi dinilai memiliki otonomi untuk menentukan strategi dan mencapai tujuan perusahaan. Lebih lanjut, Goodstein, et al. (1994) dalam (Mardiyati dan Murdayanti (2016) mengemukakan bahwa ketika ukuran dewan itu besar, kinerja keuangan dapat ditingkatkan karena sumbersumber daya penting dapat dijamin (secured) lebih mudah, seperti kontrak-kontrak keuangan dan bisnis. Kolalewski (2015) dalam penelitiannya menjelaskan bahwa terdapat keterkaitan antara tata kelola perusahaan dan kinerja perusahaan. Kinerja perusahaan yang memiliki standar tata kelola tinggi, memiliki nilai ROA yang juga tinggi. Sebaliknya, perusahaan yang memiliki standar tata kelola yang lemah, nilai ROA yang dihasilkan oleh perusahaan tersebut juga rendah. Penelitian yang dilakukan Ardiansyaha, et al. (2020) menyatakan bahwa tata kelola adalah salah satu faktor yang memengaruhi harga saham suatu perusahaan. Lebih lanjut, Ghonio (2017) menyatakan bahwa ROA dan ROE secara simultan berpengaruh positif terhadap harga saham, yang merupakan nilai perusahaan, pada perusahaan manufaktur di negara ASEAN. Kebaruan penelitian ini dilakukan dengan mengaitkan variabelvariabel dan mengintegrasikan akuntansi keuangan dalam persamaan yang dirumuskan sebagai sistem persamaan recursive dan digunakan untuk melakukan analisis dampak implementasi tata kelola perusahaan terhadap profitabilitas dan nilai perusahaan sektor nonkeuangan yang termasuk dalam indeks LQ45.

Konsep tata kelola perusahaan erat kaitannya dengan hubungan antara manajemen (direksi, dewan komisaris, komite pendukung) dengan pemilik perusahaan, sehingga ruang lingkup aspek tata kelola yang digunakan adalah ukuran direksi, komisaris independen, komite audit, kepemilikan manajerial, dan kepemilikan institusional (Tjondro dan Wilopo, 2011) dan (Noviawan dan Septiani, 2013).

Sampai dengan saat ini konsep tata kelola masih belum diimplementasikan dengan baik oleh sebagian besar pelaku dunia usaha. Hal ini tercermin dalam nilai tata kelola perusahaan Indonesia berdasarkan penilaian ASEAN Corporate Governance Scorecard (ACGS) terhadap 100 perusahaan tercatat dengan kapitalisasi pasar terbesar (OJK, 2018). Dari enam negara yang mengikuti penilaian ACGS sejak tahun 2012 sampai dengan tahun 2015, Indonesia selalu menempati urutan kelima. Kemudian baru di tahun 2017 Indonesia bergerak ke urutan keempat, yang mana peningkatan tersebut tidak berpengaruh signifikan terhadap posisi implementasi tata kelola perusahaan di Indonesia dibandingkan dengan negara lainnya. Berdasarkan uraian maka perlu dilakukan penelitian dengan tujuan untuk mendapatkan analisis mengenai faktorfaktor yang memengaruhi profitabilitas dan nilai perusahaan dan dampak faktor eksternal dan internal termasuk implementasi tata kelola perusahaan terhadap profitabilitas dan nilai perusahaan.

\section{METODE PENELITIAN}

Penelitian menggunakan pendekatan kuantitatif. Analisis untuk mencapai tujuan adalah model sistem persamaan simultan dan alternatif skenario simulasi kebijakan. Jenis data yang digunakan adalah data panel dari 14 perusahaan selama 5 tahun yang bersumber dari laporan tahunan perusahaan di Bursa Efek Indonesia periode 2014 - 2018 diakses melalui www.idx.co.id, situs web perusahaan, dan informasi resmi lembaga regulator. 
Sampel penelitian adalah perusahaan tercatat di Bursa Efek Indonesia. Pengambilan sampel dalam penelitian ini menggunakan metode purposive sampling dengan kriteria: perusahaan sektor non-keuangan di indeks LQ45 dan perusahaan yang tetap berada pada periode tahun 2014 - 2018 berjumlah 14 perusahaan. Daftar sampel perusahaan disajikan dalam Tabel 1.

Tabel 1. Daftar sampel perusahaan sektor non-keuangan indeks LQ45 di Bursa Efek Indonesia tahun 2014-2018

\begin{tabular}{lc}
\hline Sektor & $\begin{array}{c}\text { Perusahaan } \\
\text { (Ticker) }\end{array}$ \\
\hline Industri Dasar dan Kimia & SMGR \\
Industri Barang Konsumen & GGRM \\
& INDF \\
& KLBF \\
Infrastruktur, Utilitas, dan Transportasi & PGAS \\
Pertambangan & ADRO \\
& PTBA \\
Properti, Real Estate, dan Konstruksi & ADHI \\
Bangunan & PTPP \\
& WIKA \\
& WSKT \\
Perdagangan, Jasa, dan Investasi & BSDE \\
& AKRA \\
\hline
\end{tabular}

Model implementasi tata kelola perusahaan dibangun sebagai model ekonometrika dalam bentuk sistem persamaan recursive dynamic. Model terdiri dari 13 persamaan (7 persamaan struktural dan 6 persamaan identitas). Persamaan struktural (structural equation) yang juga disebut persamaan perilaku (behavioural equation). Pada 6 persamaan struktural masingmasing terdapat variabel endogen beda kala t-1 (lag endogenous variable) yang menunjukkan persamaan dan model dinamik (dynamic). Persamaan identitas (identity equation/definitional equation) merupakan persamaan akuntansi.

Tahapan spesifikasi model terdiri dari: (1) penentuan variabel endogen (endogenous variable) dan variabel penjelas (explanatory variable) dapat terdiri dari variabel endogen dan eksogen yang digunakan dalam persamaan, (2) harapan secara teoritis mengenai tanda (sign or slope) dan besaran (size or magnitude) parameter estimasi dari setiap variabel penjelas dalam persamaan, dan (3) menentukan bentuk matematik setiap persamaan struktural (Koutsoyiannis 1977).
Spesifikasi Model Implementasi Tata Kelola Perusahaan dalam bentuk sistem persamaan simultan, sebagai berikut:

1. Total Aset Perusahaan, adalah persamaan identitas/ akuntansi dan persamaannya:

$$
\mathbf{T A P}_{\mathrm{it}}=\mathrm{ALP}_{\mathrm{it}}+\mathrm{ATLP}_{\mathrm{it}}
$$

2. Total Liabilitas Perusahaan, adalah persamaan identitas/akuntansi dan persamaannya:

$$
\mathbf{T L P}_{\text {it }}=\operatorname{LLP}_{\text {it }}+\operatorname{LTLP}_{\text {it }}
$$

3. Total Ekuitas Perusahaan, adalah persamaan identitas/akuntansi dan persamaannya:

$$
\mathbf{T E} \mathbf{P}_{\text {it }}=\mathrm{MDS}_{\mathrm{it}}+\mathrm{TMD}_{\mathrm{it}}+\mathrm{SLB}_{\mathrm{it}}
$$

4. Beban Operasional Perusahaan, adalah persamaan identitas/akuntansi dan persamaannya:

$$
\mathbf{B O P}_{\text {it }}=\mathrm{BUA}_{\mathrm{it}}+\mathrm{BPP}_{\mathrm{it}}
$$

5. Revenue, adalah persamaan struktural. Merujuk pada penelitian Harahap (2019), di mana revenue dibentuk melalui variabel sebagai berikut:

$$
\begin{aligned}
& \mathbf{R E V} \mathbf{V}_{\mathrm{it}}=\mathrm{a}_{0}+\mathrm{a}_{1} \mathbf{T A P}_{\mathrm{it}}+\mathrm{a}_{2} \mathrm{INF}_{\mathrm{it}-1}+\mathrm{a}_{3} \mathrm{PDB}_{\mathrm{it}-1}+\mathrm{a}_{4} \mathrm{REV}_{\mathrm{it}-1} \\
& +\mathrm{U}_{\text {lit }} \\
& \text { Tanda parameter yang diharapkan (Hipotesis): } \mathrm{a}_{1}, \mathrm{a}_{3} \\
& >0 ; \mathrm{a}_{2}<0 ; 0<\mathrm{a}_{4}<1 .
\end{aligned}
$$

6. Laba Kotor Perusahaan, adalah persamaan identitas/ akuntansi dan persamaannya:

$$
\mathbf{L K P}_{\text {it }}=\mathbf{R E} \mathbf{V}_{\text {it }}-\mathrm{HPP}_{\text {it }}
$$

7. Earning Before Interest and Tax, adalah persamaan struktural. Merujuk pada penelitian yang dilakukan oleh Halian (2020), EBIT dibentuk melalui variabel sebagai berikut:

$\mathbf{E B I T}_{\text {it }}=\mathrm{b}_{0}+\mathrm{b}_{1} \mathbf{L K P}_{\mathrm{it}}+\mathrm{b}_{2} \mathbf{B O P}_{\mathrm{it}}+\mathrm{U}_{2 \mathrm{it}}$, Tanda parameter yang diharapkan (Hipotesis): $b_{1}>0 ; b_{2}<$ 0 .

8. Suku Bunga Riil Pinjaman Perusahaan adalah persamaan identitas/akuntansi dan persamaannya: IRT $_{t}=$ IRTN $_{t}-$ INF $_{t}$,

9. Beban Bunga Perusahaan, adalah persamaan struktural. Merujuk pada penelitian yang dilakukan oleh Halian (2020), EBIT dibentuk melalui variabel sebagai berikut:

$\mathbf{B B P} \mathbf{P}_{\mathrm{it}}=\mathrm{c}_{0}+\mathrm{c}_{1} \mathbf{T L P} \mathbf{P}_{\mathrm{it}}+\mathrm{c}_{2} \mathbf{I R T}_{\mathrm{it}}+\mathrm{c}_{3} \mathrm{BBP}_{\mathrm{it}-1}+\mathrm{U}_{3 \mathrm{it}}$ Tanda parameter yang diharapkan (Hipotesis): $\mathrm{c}_{1}, \mathrm{c}_{2}$ $>0 ; 0<\mathrm{c}_{3}<1$.

10.Laba Bersih Perusahaan, adalah persamaan struktural. Merujuk pada penelitian yang dilakukan oleh Halian (2020), LBP dibentuk melalui variabel sebagai berikut: $\mathbf{L B P}_{\text {it }}=\mathrm{d}_{0}+\mathrm{d}_{1} \mathbf{E B I T}_{\text {it }}+\mathrm{d}_{2} \mathbf{B B P}_{\text {it }}+\mathrm{d}_{3} \mathrm{BPJ}_{\mathrm{it}}+\mathrm{d}_{4} \mathrm{LBP}_{\text {it }-1}$
$+\mathrm{U}_{4 \mathrm{it}}$

Tanda parameter yang diharapkan (Hipotesis): $\mathrm{d}_{1}>$ $0 ; \mathrm{d}_{2}, \mathrm{~d}_{3}<0 ; 0<\mathrm{d}_{4}<1$. 
11. Return on Asset, adalah persamaan struktural. Merujuk pada penelitian yang dilakukan oleh Wijayanti dan Mutmainah (2012), Todorovic (2013), Noviawan dan Septiani (2013), Bhatt PR dan Bhatt RR (2017), Pizzanan et al. (2017), Attia et al. (2018), Tshipa et al. (2018), dan Halian (2020), ROA dibentuk melalui variabel sebagai berikut:

$\mathbf{R O A}_{\text {it }}=\mathrm{e}_{0}+\mathrm{e}_{1}\left(\mathrm{JDDit}_{\mathrm{JDD}} \mathrm{it-1}\right)+\mathrm{e}_{2} \mathrm{PJKI}_{\mathrm{it}}+\mathrm{e}_{3} \mathrm{KMN}_{\mathrm{it}}$ $+\mathrm{e}_{4}\left(\mathrm{KIN}_{\mathrm{it}}-\mathrm{KIN}_{\mathrm{it}-1}\right)+\mathrm{e}_{5} \mathrm{JKA}_{\mathrm{it}}+\mathrm{e}_{6} \mathbf{L B P} \mathbf{P}_{\mathrm{it}}+\mathrm{e}_{7} \mathbf{T A} \mathbf{P}_{\mathrm{it}}$ $+\mathrm{e}_{8} \mathrm{ROA}_{\mathrm{it}-1}+\mathrm{U}_{5 \mathrm{it}}$

Tanda parameter yang diharapkan (Hipotesis): $\mathrm{e}_{1}$; $\mathrm{e}_{2} ; \mathrm{e}_{3} ; \mathrm{e}_{4} ; \mathrm{e}_{5} ; \mathrm{e}_{6} ;>0$;

$\mathrm{e}_{7}<0 ; 0<\mathrm{e}_{8}<1$.

12. Return on Equity, adalah persamaan struktural. Merujuk pada penelitian yang dilakukan oleh Novrianti dan Armas (2012), Todorovic (2013), Bhatt PR dan Bhatt RR (2017), Attia et al. (2018), Tshipa et al. (2018), dan Halian (2020), ROE dibentuk melalui variabel sebagai berikut:

$\mathbf{R O E}_{\text {it }}=\mathrm{f}_{0}+\mathrm{f}_{1}\left({\text { JDDit } / J D D_{i t-1}}\right)+\mathrm{f}_{2} \mathrm{PJKI}_{\mathrm{it}}+\mathrm{f}_{3} \mathrm{KMN}_{\mathrm{it}}$ $+\mathrm{f}_{4}\left(\mathrm{KIN}_{\mathrm{it}} / \mathrm{KIN}_{\mathrm{it}-1}\right)+\mathrm{f}_{5} \mathrm{JKA}_{\mathrm{it}}+\mathrm{f}_{6} \mathbf{L B P} \mathbf{P}_{\mathrm{it}}+\mathrm{f}_{7} \mathbf{T E P}_{\mathrm{it}}+$ $\mathbf{f}_{8} \mathbf{R O E}_{\mathrm{it}-1}+\mathrm{U}_{6 \mathrm{it}}$

Tanda parameter yang diharapkan (Hipotesis): $\mathrm{f}_{1} ; \mathrm{f}_{2}$; $\mathrm{f}_{3} ; \mathrm{f}_{4} ; \mathrm{f}_{5} ; \mathrm{f}_{6}>0 ; \mathrm{f}_{7}<0 ; 0<\mathrm{f}_{8}<1$.

13. Nilai Perusahaan, adalah persamaan struktural. Merujuk pada penelitian yang dilakukan oleh Tsai (2005), TOBS dibentuk melalui variabel sebagai berikut:

TOBS $_{\mathrm{it}}=\mathrm{g}_{0}+\mathrm{g}_{1} \mathbf{R O A}_{\mathrm{it}}+\mathrm{g}_{2} \mathbf{R O E}_{\mathrm{it}}+\mathrm{g}_{3} \mathrm{MCP}_{\mathrm{it}}+$ $\mathrm{g}_{4}$ TOBS $_{\mathrm{it}-1}+\mathrm{U}_{7 \mathrm{it}}$

Tanda parameter yang diharapkan (Hipotesis): $\mathrm{g}_{1}$; $\mathrm{g}_{2} ; \mathrm{g}_{3}>0 ; 0<\mathrm{g}_{4}<1$.

Daftar variabel dalam Model Implementasi Tata Kelola Perusahaan disajikan pada Tabel 2, yang diklasifikasikan ke dalam faktor internal dan faktor eksternal. Faktor internal merupakan faktor yang berasal dari dalam perusahaan yang dapat memengaruhi secara langsung terhadap perusahaan. Sedangkan faktor eksternal adalah faktor yang berasal dari luar perusahaan dan secara tidak langsung memengaruhi perusahaan, di mana memiliki nilai yang sama setiap tahunnya untuk seluruh perusahaan. Dapat dikatakan juga bahwa faktor eksternal merupakan faktor yang tidak dapat dikendalikan oleh perusahaan yang biasanya berpengaruh pada skala industri (Athanasoglou et al. 2008 dan Allen et al. 2011 dalam Siregar et al. (2021)).
Tabel 2. Daftar variabel

\begin{tabular}{|c|c|c|}
\hline Notasi & Keterangan & Faktor \\
\hline \multicolumn{3}{|c|}{ Variabel Endogen } \\
\hline $\mathrm{TAP}_{\text {it }}$ & Total Aset Perusahaan & Internal \\
\hline $\mathrm{TLP}_{\mathrm{it}}$ & Total Kewajiban Perusahaan & Internal \\
\hline $\mathrm{TEP}_{\text {it }}$ & Total Ekuitas Perusahaan & Internal \\
\hline $\mathrm{BOP}_{\text {it }}$ & Beban Operasional Perusahaan & Internal \\
\hline $\mathrm{LKP}_{\mathrm{it}}$ & Laba Kotor & Internal \\
\hline $\mathrm{REV}_{\text {it }}$ & Revenue & Internal \\
\hline EBIT $_{\text {it }}$ & Earning Before Interest and Tax & Internal \\
\hline $\mathrm{BBP}_{\text {it }}$ & Beban Bunga Perusahaan & Internal \\
\hline $\mathrm{LBP}_{\text {it }}$ & Laba Bersih Perusahaan & Internal \\
\hline $\mathrm{ROA}_{i t}$ & Return on Asset & Internal \\
\hline $\mathrm{ROE}_{\mathrm{it}}$ & Return on Equity & Internal \\
\hline TOBS $_{i t}$ & Nilai Perusahaan & Internal \\
\hline $\mathrm{IRT}_{\text {it }}$ & $\begin{array}{l}\text { Suku Bunga Riil Pinjaman } \\
\text { Perusahaan }\end{array}$ & Eksternal \\
\hline \multicolumn{3}{|c|}{ Variabel Eksogen } \\
\hline $\mathrm{INF}_{\text {it }}$ & Tingkat Inflasi & Eksternal \\
\hline $\mathrm{PDB}_{\text {it }}$ & Produk Domestik Bruto & Eksternal \\
\hline $\mathrm{HPP}_{\text {it }}$ & Harga Pokok Penjualan & Internal \\
\hline $\mathrm{ALP}_{\text {it }}$ & Aset Lancar Perusahaan & Internal \\
\hline ATLP $_{\text {it }}$ & Aset Tidak Lancar Perusahaan & Internal \\
\hline $\operatorname{LLP}_{\text {it }}$ & Liabilitas Lancar Perusahaan & Internal \\
\hline LTLPP $_{\text {it }}$ & Liabilitas Tidak Lancar Perusahaan & Internal \\
\hline $\mathrm{JDD}_{\mathrm{it}}$ & Jumlah Anggota Direksi & Internal \\
\hline PJKI $_{\text {it }}$ & $\begin{array}{l}\text { Presentasi Jumlah Komisaris } \\
\text { Independen }\end{array}$ & Internal \\
\hline $\mathrm{KMN}_{\text {it }}$ & Kepemilikan Manajerial & Internal \\
\hline $\mathrm{KIN}_{\text {it }}$ & Kepemilikan Institusional & Internal \\
\hline $\mathrm{JKA}_{\mathrm{it}}$ & Jumlah Anggota Komite Audit & Internal \\
\hline $\mathrm{MCP}_{\text {it }}$ & Market Capitalization & Internal \\
\hline BUA $_{i t}$ & Beban Umum Administrasi & Internal \\
\hline $\mathrm{BPP}_{\text {it }}$ & Beban Penjualan Perusahaan & Internal \\
\hline IRTN $_{\text {it }}$ & $\begin{array}{l}\text { Suku Bunga Nominal Pinjaman } \\
\text { Perusahaan }\end{array}$ & Eksternal \\
\hline $\mathrm{BPJ}_{\text {it }}$ & Beban Pajak & Internal \\
\hline $\mathrm{MDS}_{\mathrm{it}}$ & Modal Disetor Perusahaan & Internal \\
\hline $\mathrm{TMD}_{\text {it }}$ & Tambahan Modal Disetor & Internal \\
\hline $\mathrm{SLB}_{\mathrm{it}}$ & Saldo Laba & Internal \\
\hline
\end{tabular}

\section{Skenario Simulasi}

Skenario simulasi dilakukan untuk menganalisis dampak faktor eksternal, internal dan tata kelola perusahaan. Penentuan angka perubahan pada simulasi faktor eksternal, internal dan tata kelola perusahaan didasari oleh nilai historis selama 5 tahun, wacana, atau rencana yang sedang berkembang, yang sumbernya didasarkan atas artikel, bahan publikasi, dan/atau pemberitaan melalui media. Simulasi faktor eksternal 
dilakukan dalam rangka melihat bagaimana dampak perubahan terhadap perusahaan. Kecenderungan nilai PDBselamatahun2014-2018terusmengalamikenaikan, namun demikian mempertimbangkan bahwa simulasi dilakukan dalam rangka memitigasi adanya ancaman dalam perekonomian, maka disimulasikan PDB turun sebesar 2,5\% berdasarkan proyeksi penurunan PDB tahun 2020. Sementara itu, kecenderungan tingkat inflasi mengalami penurunan selama 2014-2018 di mana hanya pada tahun 2016 terjadi kenaikan tingkat inflasi, sehingga disimulasikan tingkat inflasi naik sebesar 50 basis poin. Untuk meresponnya, perusahaan melakukan kebijakan perubahan faktor internal, yang nilainya didasarkan atas pertimbangan nilai historis kenaikan dan kewajaran. Angka yang digunakan tidak pasti sama dengan rata-rata historical data yang telah dimiliki. Terdapat adjustment $1-2 \%$ dari nilai rata-rata historis sebagai respon terhadap adanya perubahan faktor eksternal.

Alternatif skenario simulasi yang dilakukan sebagai berikut:

1. S1: Produk Domestik Bruto (PDB) turun sebesar $2,5 \%$.

2. S2: Tingkat inflasi naik sebesar 50 basis poin.

3. S3: Peningkatan tata kelola perusahaan (kepemilikan manajerial naik sebesar 10\%, kepemilikan institusional naik sebesar $10 \%$, jumlah direksi naik sebesar $15 \%$,presentasijumlahkomisarisindependen (JKI) naik sebesar 15\%, dan jumlah anggota komite audit naik sebesar 30\%). (Perhitungan presentase peningkatan jumlah anggota direksi, komite audit, dan komisaris independen sama dengan peningkatan 1 orang untuk masing-masing variabel).

4. S4: Produk domestik bruto turun sebesar $2,5 \%$, peningkatan tata kelola perusahaan, dan harga pokok penjualan perusahaan turun sebesar $2 \%$.

5. S5: Produk domestik bruto turun sebesar $2,5 \%$, peningkatan tata kelola perusahaan, penurunan beban operasional perusahaan (beban umum administrasi turun sebesar 3\% dan beban penjualan perusahaan turun sebesar 5\%), dan peningkatan total aset perusahaan (aset lancar perusahaan naik sebesar $1 \%$ dan aset tidak lancar perusahaan naik sebesar $2 \%$ ).

6. S6: Tingkat inflasi naik sebesar 50 basis poin, peningkatan tata kelola perusahaan, dan harga pokok penjualan perusahaan turun sebesar $2 \%$.

7. S7: Tingkat inflasi naik sebesar 50 basis poin, peningkatan tata kelola perusahaan, penurunan beban operasional perusahaan (beban umum administrasi turun sebesar 3\% dan beban penjualan perusahaan turun sebesar 5\%), dan peningkatan total aset perusahaan (aset lancar perusahaan naik sebesar $1 \%$ dan aset tidak lancar perusahaan naik sebesar 2\%).

Berdasarkan uraian latar belakang dan masalah yang telah dijelaskan, maka kerangka pemikiran penelitian disajikan pada Gambar 3. Terdapat 2 tujuan yang akan dianalisis melalui penelitian ini, yaitu menganalisis faktor-faktor yang memengaruhi profitabilitas dan nilai perusahaan dan menganalisis dampak faktor eksternal, internal dan tata kelola terhadap profitabilitas dan nilai perusahaan yang termasuk ke dalam indeks LQ45 di Bursa Efek Indonesia.

\section{HASIL}

Model perlu diidentifikasi terlebih dahulu sebelum diestimasi dan identifikasi persamaan struktural menggunakan order condition (Koutsoyiannis 1977). Hasil identifikasi model adalah over identified dan model diestimasi menggunakan metode Two Stage Least Squares (2SLS). Sebelum dilakukan simulasi, model divalidasi dengan menggunakan kriteria Theil's Inequality Coefficient (U-Theil).

\section{Hasil Estimasi Model}

Model Implementasi Tata Kelola Perusahaan terdiri dari 13 persamaan, yaitu 7 persamaan struktural dan 6 persamaan identitas. Estimasi model hanya dilakukan terhadap parameter persamaan struktural. Seluruh hasil estimasi parameter variabel penjelas pada persamaan struktural memiliki tanda sesuai dengan harapan (hipotesis).

Berdasarkan kriteria ekonomi, seluruh hasil estimasi parameter variabel penjelas yang dimasukkan ke dalam masing-masing persamaan struktural memiliki tanda sesuai dengan harapan (hipotesis). Kriteria statistik yang digunakan untuk mengevaluasi hasil estimasi adalah koefisien determinasi $\left(\mathrm{R}^{2}\right)$. Seluruh persamaan memiliki nilai koefisien determinasi $\left(\mathrm{R}^{2}\right)$ di atas 0,61 . Persamaan struktural yang memiliki koefisien deteinasi $\left(\mathrm{R}^{2}\right)$ terbesar terdapat pada persamaan laba bersih perusahaan (LBP) dengan nilai sebesar 0,98 dan nilai terkecil terdapat pada persamaan nilai perusahaan (TOBS) dengan nilai sebesar 0,62 , berdasarkan uji $\mathrm{F}$ semua nyata pada taraf $\alpha<1 \%$. Kriteria ekonometrika 
menggunakan indikator multikolinearitas dengan mengestimasi nilai Variance Inflation Factor (VIF) pada setiap persamaan. Hasil estimasi nilai VIF pada semua persamaan struktural lebih kecil dari 10, sehingga tidak terdapat masalah multikolinearitas.

Faktor-faktor yang memengaruhi profitabilitas dan nilai perusahaan (uji-t pada taraf nyata $\alpha \leq 15 \%$ ) adalah revenue perusahaan (REV) dipengaruhi secara signifikan oleh total aset perusahaan (TAP), produk domestik bruto (PDBT), dan REV lag $\mathrm{t}_{-1}$. Earning before interest and tax (EBIT) dipengaruhi secara signifikan oleh laba kotor perusahaan (LKT), dan beban operasional perusahaan (BOP). Beban bunga perusahaan (BBP) dipengaruhi secara signifikan oleh total liabilitas perusahaan (TLP) dan BBP lag $t_{-1}$. Laba bersih perusahaan (LBP) dipengaruhi secara signifikan oleh earning before interest and tax (EBIT), beban bunga perusahaan (BBP), beban pajak perusahaan (BPJ), dan LBP lag $t_{-1}$. Return on Asset (ROA) dipengaruhi secara signifikan oleh rasio jumlah anggota direksi (RJDD), presentasi jumlah komisaris independen (PJKI), jumlah komite audit (JKA), laba bersih perusahaan (LBP), total aset perusahaan (TAP), dan ROA lag $\mathrm{t}_{-1}$. Return on Equity (ROE) dipengaruhi secara signifikan oleh rasio jumlah anggota direksi (RJDD), presentasi jumlah komisaris independen (PJKI), jumlah komite audit (JKA), kepemilikan manajerial (KMN), laba bersih perusahaan (LBP), total ekuitas perusahaan (TEP), dan ROE lag $t_{-1}$. Nilai Perusahaan (TOBS) dipengaruhi oleh return on asset (ROA), return on equity (ROE), market capitalization (MCP), dan TOBS lag $\mathrm{t}_{-1}$.

\section{Hasil Alternatif Skenario Simulasi}

Hasil validasi model cukup baik, maka model dapat digunakan untuk simulasi perubahan faktor eksternal dan kebijakan perusahaan. Hasil simulasi dampak faktor eksternal dan faktor internal termasuk implementasi tata kelola perusahaan terhadap profitabilitas dan nilai perusahaan disajikan pada Tabel 3. Berdasarkan Tabel 3 dapat dijelaskan bahwa pada kondisi produk domestik bruto (PDB) turun sebesar 2,5\%, berdampak terhadap penurunan revenue perusahaan, laba kotor perusahaan, earning before interest and tax, laba bersih perusahaan, return on asset, return on equity, dan nilai perusahaan. Penurunan PDB berdampak negatif paling besar terhadap return on asset dibandingkan dengan return on equity dan nilai perusahaan (Skenario 1).

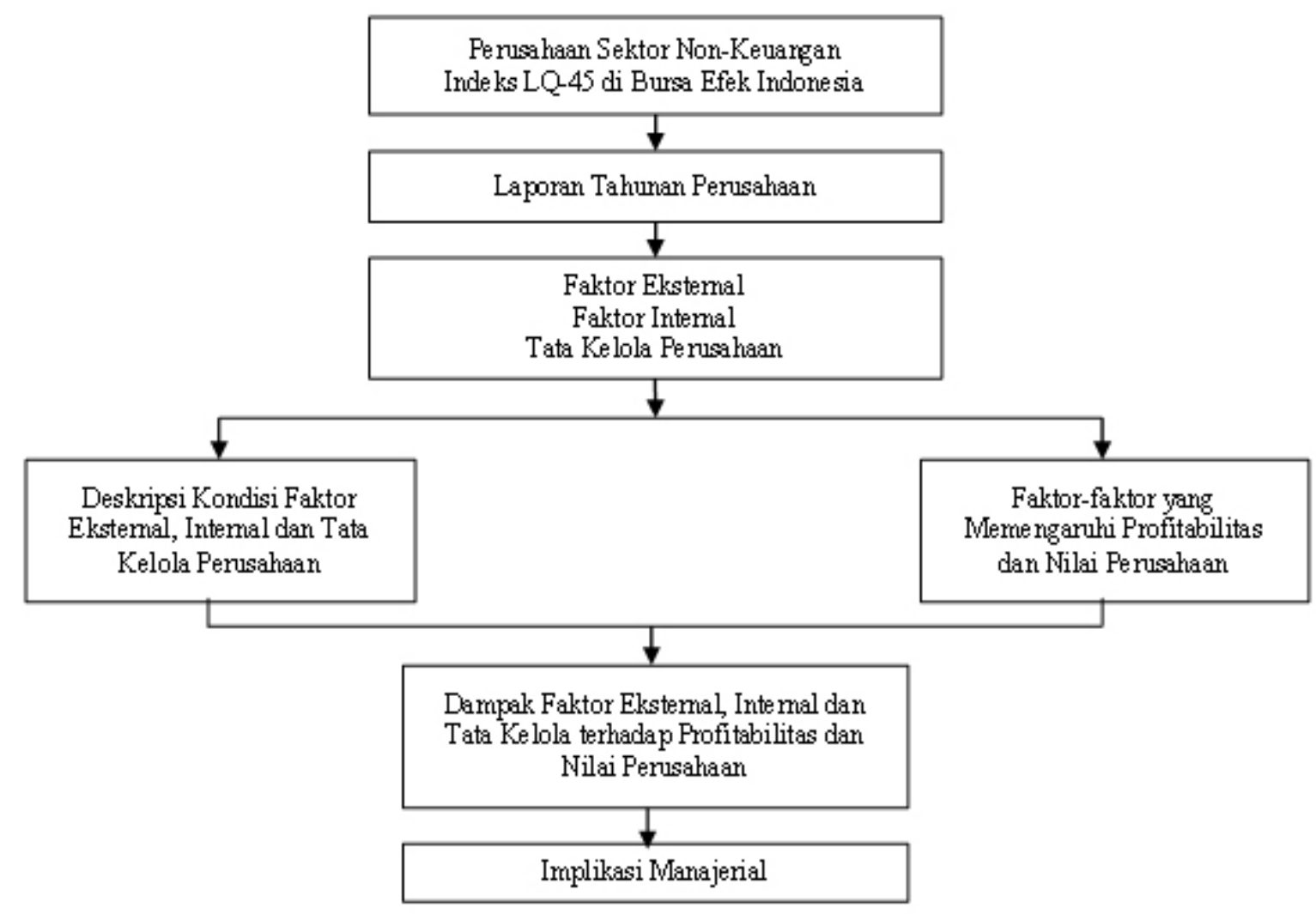

Gambar 3. Kerangka pemikiran penelitian 
Tabel 3. Dampak faktor eksternal dan faktor internal termasuk implementasi tata kelola perusahaan terhadap profitabilitas dan nilai perusahaan

\begin{tabular}{|c|c|c|c|c|c|c|c|c|c|}
\hline \multirow{2}{*}{ Variabel } & \multirow{2}{*}{ Satuan } & \multirow{2}{*}{$\begin{array}{l}\text { Nilai Dasar } \\
\text { (Rp Jt) }\end{array}$} & \multicolumn{7}{|c|}{ Dampak Skenario Simulasi (\%) } \\
\hline & & & S1 & S2 & S3 & S4 & S5 & S6 & S7 \\
\hline TAP & Juta $\mathrm{Rp}$ & $41.434 .000,49$ & 0,00 & 0,00 & 0,00 & 0,00 & 1,52 & 0,00 & 1,52 \\
\hline TLP & Juta $\mathrm{Rp}$ & $20.820 .451,71$ & 0,00 & 0,00 & 0,00 & 0,00 & 0,00 & 0,00 & 0,00 \\
\hline TEP & Juta Rp & $17.604 .748,40$ & 0,00 & 0,00 & 0,00 & 0,00 & 0,00 & 0,00 & 0,00 \\
\hline BOP & Juta $R p$ & 2.773.738,17 & 0,00 & 0,00 & 0,00 & 0,00 & $-4,04$ & 0,00 & $-4,04$ \\
\hline REV & Juta $R p$ & $26.978 .672,99$ & $-0,84$ & $-0,03$ & 0,00 & $-0,84$ & 0,78 & $-0,03$ & 1,59 \\
\hline LKP & Juta $R p$ & $7.221 .346,38$ & $-3,15$ & $-0,10$ & 0,00 & 2,33 & 2,90 & 5,37 & 5,95 \\
\hline EBIT & Juta Rp & $4.419 .646,23$ & $-5,00$ & $-0,16$ & 0,00 & 3,69 & 6,94 & 8,53 & 11,77 \\
\hline IRT & $\%$ & 7,94 & 0,00 & $-0,06$ & 0,00 & 0,00 & 0,00 & $-0,06$ & $-0,06$ \\
\hline BBP & Juta Rp & $609.000,92$ & 0,00 & $-1,22$ & 0,00 & 0,00 & 0,00 & $-1,22$ & $-1,22$ \\
\hline LBP & Juta Rp & $3.011 .591,15$ & $-6,93$ & $-0,04$ & 0,00 & 5,11 & 9,62 & 12,00 & 16,51 \\
\hline ROA & Rasio & 8,41 & $-6,14$ & $-0,03$ & 33,77 & 38,20 & 40,71 & 44,31 & 46,82 \\
\hline ROE & Rasio & 18,37 & $-5,79$ & $-0,03$ & 17,53 & 21,78 & 25,56 & 27,54 & 31,32 \\
\hline TOBS & Rasio & 2,10 & $-6,02$ & $-0,03$ & 32,47 & 36,67 & 39,36 & 42,65 & 45,34 \\
\hline
\end{tabular}

Pada kondisi tingkat inflasi naik sebesar 50 basis poin, berdampak terhadap penurunan revenue perusahaan, laba kotor perusahaan, earning before interest and tax, suku bunga riil pinjaman perusahaan, beban bunga perusahaan, laba bersih perusahaan, return on asset, return on equity, dan nilai perusahaan. Kenaikan tingkat inflasi berdampak negatif sama besarnya terhadap return on asset, return on equity, dan nilai perusahaan (Skenario 2). Rendahnya nilai simulasi menunjukkan bahwa perubahan kenaikan tingkat inflasi sebesar 50 basis poin tidak memiliki pengaruh signifikan terhadap profitabilitas dan nilai perusahaan, di mana pasar dapat menerima perubahan kenaikan tingkat inflasi tersebut. Meskipun demikian, simulasi terhadap perubahan tingkat inflasi ini tetap dilakukan mempertimbangkan bahwa tingkat inflasi merupakan salah satu instrumen makroekonomi penting yang memengaruhi kestabilan perekonomian.

Pada saat terjadi perubahan kebijakan perusahaan yaitu implementasi tata kelola perusahaan yang terdiri dari kepemilikan manajerial naik sebesar 10\%, kepemilikan kepemilikan institusional naik sebesar $10 \%$, jumlah direksi naik sebesar $15 \%$, presentasi JKI naik sebesar $15 \%$, dan jumlah anggota komite audit naik sebesar $30 \%$, berdampak terhadap kenaikan return on asset, return on equity, dan nilai perusahaan. Peningkatan tata kelola perusahaan berdampak positif paling besar terhadap return on asset dibandingkan dengan return on equity dan nilai perusahaan (Skenario 3).
Pada kondisi penurunan produk domestik bruto sebesar 2,5\%, peningkatan tata kelola perusahaan, dan penurunan harga pokok penjualan sebesar $2 \%$, berdampak terhadap penurunan revenue perusahaan. Namun demikian, terjadi kenaikan laba kotor perusahaan, earning before interest and tax, laba bersih perusahaan, return on asset, return on equity, dan nilai perusahaan. Penurunan produk domestik bruto di mana perusahaan mengatasinya melalui kebijakan peningkatan tata kelola perusahaan, dan efisiensi penurunan harga pokok penjualan berdampak positif paling besar terhadap return on asset dibandingkan dengan return on equity dan nilai perusahaan (Skenario 4).

Pada kondisi penurunan produk domestik bruto sebesar $2,5 \%$, peningkatan tata kelola perusahaan, penurunan beban operasional perusahaan, dan peningkatan total aset perusahaan, berdampak terhadap penurunan beban operasional perusahaan, peningkatan revenue perusahaan, laba kotor perusahaan, earning before interest and tax, laba bersih perusahaan, return on asset, return on equity, dan nilai perusahaan. Penurunan produk domestik bruto di mana perusahaan mengatasinya melalui kebijakan peningkatan tata kelola perusahaan, efisiensi penurunan beban operasional perusahaan, dan peningkatan total aset perusahaan, berdampak positif paling besar terhadap return on asset dibandingkan dengan return on equity dan nilai perusahaan. (Skenario 5). 
Pada kondisi tingkat inflasi meningkat sebesar 50 basis poin, peningkatan tata kelola perusahaan, dan penurunan harga pokok penjualan sebesar $2 \%$, berdampak terhadap penurunan revenue perusahaan, suku bunga riil perusahaan, dan beban bunga perusahaan. Namun demikian, terjadi kenaikan laba kotor perusahaan, earning before interest and tax, laba bersih perusahaan, return on asset, return on equity, dan nilai perusahaan. Kenaikan tingkat inflasi di mana perusahaan mengatasinya melalui kebijakan peningkatan tata kelola perusahaan, dan efisiensi penurunan harga pokok penjualan berdampak positif paling besar terhadap return on asset dibandingkan dengan return on equity dan nilai perusahaan (Skenario $6)$.

Pada kondisi tingkat inflasi meningkat sebesar 50 basis poin, peningkatan tata kelola perusahaan, penurunan beban operasional perusahaan, dan peningkatan total aset perusahaan, berdampak terhadap suku bunga riil pinjaman perusahaan dan beban bunga perusahaan. Namun demikian, kenaikan tersebut tidak lebih besar dibandingkan dengan penurunan beban operasional perusahaan, peningkatan total aset perusahaan, revenue perusahaan, laba kotor perusahaan, earning before interest and tax, laba bersih perusahaan, return on asset, return on equity, dan nilai perusahaan. Kenaikan tingkat inflasi di mana perusahaan mengatasinya melalui kebijakan peningkatan tata kelola perusahaan, efisiensi penurunan beban operasional perusahaan, dan peningkatan total aset perusahaan, berdampak positif paling besar terhadap return on asset dibandingkan dengan return on equity dan nilai perusahaan. (Skenario 7).

\section{Rekapitulasi Simulasi}

Pada kondisi perubahan faktor eksternal yaitu penurunan produk domestik bruto atau peningkatan tingkat inflasi berdampak terhadap penurunan return on asset, return on equity, dan nilai perusahaan. Dampak negatif paling besar terjadi pada saat produk domestik bruto mengalami penurunan dibandingkan dengan peningkatan tingkat inflasi. Pada kondisi peningkatan tata kelola perusahaan yang terdiri dari kepemilikan manajerial sebesar $10 \%$, kepemilikan institusional $10 \%$, jumlah direksi sebesar $15 \%$, presentasi jumlah komisaris independen sebesar $15 \%$, dan jumlah anggota komite audit sebesar 30\%, berdampak positif terhadap peningkatan return on asset, return on equity, dan nilai perusahaan.
Pada kondisi penurunan produk domestik bruto sebesar $2,5 \%$ yang diatasi perusahaan dengan meningkatkan tata kelola perusahaan, dan melakukan efisiensi dengan menurunkan harga pokok penjualan sebesar 2\%, berdampak positiflebih besar terhadap profitabilitas dan nilai perusahaan dibandingkan yang diatasi perusahaan dengan meningkatkan tata kelola perusahaan dan menurunkan harga pokok penjualan sebesar 2\%. Pada kondisi kenaikan tingkat inflasi yang diatasi perusahaan dengan meningkatkan tata kelola perusahaan, dan melakukan efisiensi dengan menurunkan harga pokok penjualan sebesar $2 \%$, berdampak positif lebih besar terhadap profitabilitas dan nilai perusahaan dibandingkan yang diatasi perusahaan dengan meningkatkan tata kelola perusahaan dan menurunkan harga pokok penjualan sebesar $2 \%$. Berdasarkan pada kondisi perubahan faktor eksternal, dampak terhadap profitabilitas dan nilai perusahaan paling besar terjadi jika perusahaan mengatasinya dengan meningkatkan tata kelola perusahaan, melakukan efisiensi melalui penurunan beban operasional perusahaan, dan meningkatkan total aset perusahaan. Peningkatan tata kelola perusahaan perlu dilakukan karena sesuai dengan simulasi skenario 3, terjadi peningkatan ROA sebesar $33,77 \%$, ROE sebesar $17,53 \%$, dan TOBS sebesar $32,47 \%$. Peningkatan tata kelola cateris paribus dengan variabel lainnya, karena peningkatan jumlah direksi sebesar 15\% (1 orang), jumlah anggota komite audit sebesar 30\% (1 orang), dan presentasi jumlah komisaris independen sebesar 30\% (1 orang), diasumsikan tidak memberikan kenaikan signifikan terhadap beban operasional.

\section{Implikasi Manajerial}

Dalam rangka meningkatkan profitabilitas dan nilai perusahaan sektor non-keuangan yang termasuk indeks LQ45 pada kondisi (1) produk domestik bruto menurun atau (2) tingkat inflasi meningkat, perusahaan disarankan untuk meningkatkan implementasi tata kelola perusahaan, menurunkan beban operasional dan meningkatkan total aset perusahaan dengan meningkatkan jumlah anggota direksi, proporsi komisaris independen, jumlah anggota komite audit, kepemilikan manajerial, dan kepemilikan institusional, dengan menurunkan beban umum administrasi dan beban penjualan perusahaan, (baik aset lancar dan aset tidak lancar perusahaan). Bagi investor, pada perubahan faktor eksternal menunjukkan kondisi (1) produk domestik bruto menurun atau (2) tingkat inflasi meningkat, yang berdampak terhadap penurunan 
kinerja keuangan perusahaan, maka investor disarankan menerapkan prinsip prudensial dalam menentukan keputusan investasi. Selain itu, investor juga disarankan untuk dapat meningkatkan awareness terhadap perusahaan yang mengimplementasikan tata kelola perusahaan. Selanjutnya, bagi pemerintah selaku regulator yang memiliki kewenangan untuk mengatur dan mengawasi perusahaan tercatat di Indonesia seharusnya dapat bertindak secara tegas dalam meningkatkan penerapan tata kelola perusahaan yang baik. Adapun contoh yang dapat dilakukan adalah misalnya melalui pelaksanaan sosialisasi berkala terkait urgensi tata kelola perusahaan, mendorong pendidikan dan pelatihan bagi direksi dan dewan komisaris dengan tema khusus mengenai tata kelola perusahaan, memberikan insentif/sweetener bagi perusahaan yang telah menerapkan tata kelola perusahaan yang baik, dan menyusun atau menyempurnakan kebijakan terkait tata kelola perusahaan yang baik.

\section{KESIMPULAN DAN SARAN}

\section{Kesimpulan}

Faktor-faktor yang memengaruhi profitabilitas dan nilai perusahaan dilihat berdasarkan alur struktur sistem persamaan adalah revenue perusahaan dipengaruhi oleh total aset perusahaan (TAP), produk domestik bruto (PDBT), dan REV tahun lalu. Earning before interest and tax (EBIT) dipengaruhi oleh laba kotor perusahaan (LKT) dan beban operasional perusahaan (BOP). Beban bunga perusahaan (BBP) dipengaruhi oleh total liabilitas perusahaan (TLP) dan BBP tahun lalu. Laba bersih perusahaan (LBP) dipengaruhi oleh earning before interest and tax (EBIT), beban bunga perusahaan (BBP), beban pajak perusahaan (BPJ), dan LBP tahun lalu. Profitabilitas perusahaan yaitu Return on Asset (ROA) dipengaruhi oleh presentasi jumlah komisaris independen (PJKI), jumlah komite audit (JKA), laba bersih perusahaan (LBP), total aset perusahaan (TAP), dan ROA tahun lalu. Profitabilitas perusahaan yaitu Return on Equity (ROE) dipengaruhi oleh rasio jumlah anggota direksi (RJDD), presentasi jumlah komisaris independen (PJKI), jumlah komite audit (JKA), kepemilikan manajerial (KMN), laba bersih perusahaan (LBP), dan total ekuitas perusahaan (TEP) dan Nilai Perusahaan (TOBS) dipengaruhi oleh return on asset (ROA) dan TOBS tahun lalu.
Analisis simulasi kebijakan dapat dilihat bahwa pada kondisi penurunan produk domestik bruto dibandingkan dengan peningkatan tingkat inflasi memiliki dampak lebih besar terhadap penurunan profitabilitas dan nilai perusahaan. Penurunan produk domestik bruto yang diatasi perusahaan dengan kebijakan meningkatkan tata kelola (meningkatkan jumlah anggota direksi, presentasi jumlah komisaris independen, jumlah anggota komite audit, kepemilikan manajerial, dan kepemilikan institusional) akan lebih efektif meningkatkan profitabilitas dan nilai perusahaan dengan melakukan efisiensi menurunkan beban operasional dan meningkatkan total aset dibandingkan melakukan efisiensi penurunan harga pokok penjualan. Sedangkan pada kondisi peningkatan tingkat inflasi yang diatasi perusahaan dengan kebijakan meningkatkan tata kelola (meningkatkanjumlahanggotadireksi,presentasijumlah komisaris independen, jumlah anggota komite audit, kepemilikan manajerial, dan kepemilikan institusional) akan lebih efektif meningkatkan profitabilitas dan nilai perusahaan dengan melakukan efisiensi menurunkan beban operasional dan meningkatkan total aset dibandingkan melakukan efisiensi penurunan harga pokok penjualan.

\section{Saran}

Perusahaan dapat melakukan peninjauan ulang terhadap implementasi tata kelola di perusahaannya masingmasing. Jika tingkat implementasi perusahaan rendah, sebaiknya perusahaan meningkatkan implementasi tata kelola perusahaan dengan tetap mengacu kepada peraturan perundang-undangan dalam rangka menjaga dan meningkatkan kinerja keuangannya. Selain itu, bagi penelitian selanjutnya dapat melakukan analisis cost and benefit terhadap implementasi tata kelola perusahaan, misalnya dengan mengkaitkan pemilihan variabel tata kelola yang berupa jumlah individu dengan beban perusahaan. Selain itu dapat memasukkan variabel tata kelola perusahaan yang lain seperti komite nominasi dan remunerasi, remunerasi, sekretaris perusahaan, audit internal, serta durasi penelitian yang lebih panjang sehingga didapatkan hasil analisis penelitian yang lebih komprehensif.

\section{DAFTAR PUSTAKA}

Adam M, Taufik, Wahyudi T, Raneo AP, Muizzudin. 2018. Do traditional accounting and economic value added mediate the relationship between 
corporategovernance and firm value ofIndonesian state-owned enterprises? International Journal of Economics and Financial Issues 8(3): 118126.

Alqatan A, Chbib I, Khaled H. 2019. How does board structure impact on firm performance in the UK? Corporate Board: Role, Duties and Composition 5(2): 18-27.

Ardiansyaha F, Hermanto S, Dedi BH, Mulya S. 2020. Determinants affecting profitability and stock returns for smaller banks listed on the indonesia stock exchange. Jurnal Aplikasi Manajemen dan Bisnis 6(3): 679-690.

Attia MBR, Lassoued N, Chouikha M. 2018. State ownership and firm profitability in emerging markets - a simultaneous equations analysis. International Journal of Public Sector Management 31(2): 167-183.

[BEI] PT. Bursa Efek Indonesia. 2019. Laporan tahunan 2018. Jakarta: PT. Bursa Efek Indonesia.

Bhatt, P. R., Bhatt, R. R. 2017. Corporate governance and firm performance in Malaysia. The International Journal of Business in Society. 17(5): 896-912.

CEICData. 2019. Hubungan antara kapitalisasi pasar terhadap PDB Indonesia tahun 20102017. https://www.ceicdata.com/id/indicator/ indonesia/market-capitalization--nominal-gdp. [2019 Maret 15].

Claessens S, Burcin YB. 2012. Corporate governance in emerging markets: a survey. Emerging Markets Review. 15(3): 1-33.

Daniri, MA. 2014. Lead by GCG. Jakarta: Gagas Bisnis.

Fahmi I. 2014. Manajemen Keuangan Perusahaan dan Pasar Modal. Jakarta: Mitra Wacana Media.

Ghonio MG, Sukirno S. 2017. Pengaruh return on asset (ROA) dan return on equity (ROE) terhadap harga saham pada perusahaan manufaktur yang terdaftar di ASEAN periode 2013-2015. Jurnal Profita. 4: 1-13.

Halian W, Sinaga BM, Novianti T. 2020. Factors affecting profitability of construction company sub-sector. Indonesian Journal of Business and Entrepreneurship 6(2): 118-126.

Harahap M, Sinaga BM, Manurung AH, Maulana TNA. 2018. Dampak kebijakan dan makroekonomi terhadap efektivitas penerimaan pajak di Bursa Efek Indonesia. Jurnal Ilmiah Manajemen 8(2): 400-419.

[IICG] Indonesian Institute for Corporate Governance. 2010. Laporan corporate governance perception index 2009 - corporate governance sebagai budaya. Jakarta: Indonesian Institute for Corporate Governance.

Mardiyati U, Murdayanti Y. 2016. Pengaruh ukuran dewan, kepemilikan saham oleh direktur, dan jender terhadap kinerja keuangan perbankan. Jurnal Manajemen 20(3): 402-415.

Noviawan RA, Septiani A. 2013. Pengaruh mekanisme corporate governance dan struktur kepemilikan terhadap kinerja keuangan. Diponegoro Journal of Accounting 2(3): 2337-3806.

Novrianti V, Armas R. 2012. Pengaruh corporate social responsibility dan good corporate governance terhadap kinerja perusahaan (studi pada perusahaan manufaktur di BEI tahun 20092011). Jurnal Akuntansi 1(1):1-11.

[OECD] Organization for Economic Co-operation and Development. 2010. Annual Report 2009. Paris: Organization for Economic Co-operation and Development.

[OJK] Otoritas Jasa Keuangan. 2014. Roadmap tata kelola perusahaan Indonesia. Jakarta: Otoritas Jasa Keuangan.

[OJK] Otoritas Jasa Keuangan. 2018. Materi presentasi sosialisasi ACGS 2018. Jakarta: Otoritas Jasa Keuangan.

Koutsoyiannis A. 1977. Theory of Econometrics: An Introductory Exposition of Econometric Methods. Second Edition. London: The MacMillan Press Ltd.

Pizzanan LS, Paramita PD, Suprijanto A. 2017. The effect of ownership structure on stock price with financial performance as intervening variable (studi kasus pada perusahaan makanan dan minuman yang terdaftar di Bursa Efek Indonesia tahun 2011-2016). Jurnal Universitas Pandanaran 3(3): 1 - 20.

Prasetyanto, PK. 2016. Pengaruh produk domestik bruto dan inflasi terhadap indeks harga saham gabungan di Bursa Efek Indonesia tahun 2002-2009. Jurnal Riset Akuntansi dan Bisnis Airlangga 1(1): 60 - 84.

Siregar AAP, Achsani NA, Sasongko H. 2021. Pengaruh tax amnesty terhadap profitabilitas perusahaan yang terdaftar di bursa efek Indonesia. Jurnal Aplikasi Manajemen dan Bisnis 7(1): 86-97.

Syafitri T, Nuzula NF, Nurlaily F. 2018. Pengaruh good corporate governance terhadap nilai perusahaan (Studi pada perusahaan industri sub sektor logam dan sejenisnya yang terdaftar di BEI periode 2012-2016). Jurnal Administrasi Bisnis 56(1): 
118-126.

Tjondro D, Wilopo R. 2011. Pengaruh good corporate governance (GCG) terhadap profitabilitas dan kinerja saham perusahaan perbankan yang tercatat di Bursa Efek Indonesia. Journal of Business and Banking 1(1): 1 - 14 .

Todorovic I. 2013. Impact of corporate governance on performance of companies. Montenegrin Journal of Economics 9(2): 47-53.

Tsai M. 2005. The impact of institutional ownership on firm performance in the hospitality industry. [disertasi]. Las Vegas: University of Nevada.

Tshipa J, Brümmer L, Wolmarans H, du Toit E. 2018. Corporate governance and financial performance in the midst of exogenous shocks: a study of companies listed on the Johannesburg Stock Exchange. Journal of the Southern African
Institute for Management Scientists 27(1): 2038.

Turel A, Belverd ENJr, Evren DS. 2012. Corporate governance in Turkey: issues and practices of high-performance companies. Journal of Accounting and Management Information Systems 11(4): 510-531.

Wijayanti S, Mutmainah S. 2012. Pengaruh penerapan corporate governance terhadap kinerja keuangan pada perusahaan perbankan yang terdaftar di bursa efek indonesia (BEI) Tahun 2009-2011. Diponegoro Journal of Accounting 1(1): 135149.

Zarkasyi W. 2008. Good Corporate Governance Pada Badan Usaha Manufaktur, Perbankan, dan Jasa Keuangan Lainnya. Bandung: Alfabeta. 